\title{
Soil Properties Affecting Rainfall Water Use Efficiency (RWUE) in Wheat Dry-Farming Lands, NW Iran
}

\author{
Ali Reza Vaezi ${ }^{1}$ \\ ${ }^{1}$ Department of Soil Science, Agriculture Faculty, University of Zanjan, Zanjan, Iran \\ Correspondence: Ali Reza Vaezi, Department of Soil Science, Agriculture Faculty, University of Zanjan, Zanjan, \\ Iran. Tel: 98-241-515-2438. E-mail: vaezi.alireza@gmail.com
}

Received: April 1, 2012 Accepted: May 3, 2013 Online Published: May 15, 2013

doi:10.5539/jas.v5n6p9 URL: http://dx.doi.org/10.5539/jas.v5n6p9

\begin{abstract}
Effective use of rainfall water is a key issue in agricultural development in the arid and semi-arid regions since rainfall water is a precondition for crop production there. This study was conducted in a semi-arid agricultural region with $900 \mathrm{~km}^{2}$ in area in Hashtroud, northwest of Iran to determine the relationship between rainwater use efficiency (RWUE) and soil properties. Winter wheat yield and soil properties were determined at 108 plots $\left(40.41 \mathrm{~m}^{2}\right.$ in area) installed in thirty six dry-farming lands. RWUE of each plot obtained from the ratio of crop dry matter per unit of abstracted rainfall water volume (ARWV). ARWV was computed from deduction of the rainfall and runoff volume during a two-growth period. Runoff data for each land was obtained from field measurements at the plots under natural rainfalls. Analysis of rainfalls uniformity using four rain gauge stations data showed that spatial distributions of rainfalls were homogeneous in the area. The RWUE values in the lands were ranged from $0.35 \mathrm{~kg} \mathrm{~m}^{-3}$ to $1.49 \mathrm{~kg} \mathrm{~m}^{-3}$ with an average of $0.84 \mathrm{~kg} \mathrm{~m}^{-3}$. Soil properties which considerably affected either the infiltration capacity or the available water controlled the RWUE in the study area. Multi-regression analysis indicated that the RWUE significantly related to silt, organic matter and lime $\left(\mathrm{R}^{2}=0.82\right.$, $\mathrm{p}<0.001$ ). Maintaining crop residues and incorporating with the soil can be proper techniques and sustainable strategies to improve the soil properties and enhance the RWUE in the dry-farming lands.
\end{abstract}

Keywords: available water, infiltration capacity, semi-arid region, natural rainfall, winter wheat

\section{Introduction}

Precipitation is one of the most important factors affecting agricultural productions, especially in the arid and semi-arid regions. Water from precipitation must be captured and retained in soil and used efficiently for optimum yield production (Morell et al., 2011). Effective use of rainfall water is a key issue in agricultural development in the arid and semi-arid regions since rainfall water is a precondition for crop production there. RWUE is the ratio of crop dry matter per unit of abstracted rainfall water volume (ARWV). The abstracted rainfall water volume is a part of precipitation that could be stored in soil. The RWUE is often considered an important determinant of yield under stress and even as a component of crop drought resistance. It has been used to imply that rainfed plant production can be increased per unit water used, resulting in "more crop per drop" (Blum, 2009).

A major research challenge is to investigate methods that maximize wheat yield and the RWUE. It has been concluded that most of the agronomic options for improving RWUE in rainfed agricultural systems decrease water losses by declining soil evaporation, runoff, through flow, deep drainage, and competing weeds, thereby making more water available for increased water use by the crop (Asseng et al., 2001; Turner, 2004). Soil properties are one of the most important factors influencing crop water availability due to their effects on the water holding capacity, evaporation, and runoff generation. Rainfall water use efficiency (RWUE) decreases when both plant water supplying in the soil decreases and runoff generation increases. The supplied water for the plant (available water, AW) is that portion of water held in soil that can be absorbed by plant roots (Richards \& Wadleigh, 1952). AW is the amount of water between the field capacity (FC) and the permanent wilting point (PWP) (Veihmeyer \& Hendrickson, 1927) that may strongly affected by some soil properties particularly texture and structure. Soil properties also affect on runoff rate in the land. Runoff occurs only when the rate of rainfall on a surface exceeds the rate at which water can infiltrate the soil (Schwab et al., 1993). Runoff more commonly occurs in the arid and semi-arid regions, where rainfall intensities are high and the soil infiltration capacity is 
reduced because of surface sealing, or in paved areas. The rate of infiltration of water into the soil depends on several soil properties, particularly physical characteristics of the soil (Ghawi \& Battikhi, 1986).

Almost 39 percent of Iran $\left(642797 \mathrm{~km}^{2}\right)$ has a semi-arid climate condition, with an annual precipitation between 200 and $500 \mathrm{~mm}$. East-Azarbijan province located in north west of Iran is one of the typical semi-arid regions, with an mean annual precipitation of $300 \mathrm{~mm}$ (Modarres, 2006). On average, precipitation has a nonuniform annual distribution, with the major part occurring in early spring (37\%), middle autumn $(26 \%)$ and early winter (31\%) and little precipitation in summer (6\%) (Anonymous, 2011). The arable area is estimated to be about 1220980 ha (27 percent of total surface area). Farming is mostly done in rainfed condition (813119 ha) and water is the principal limiting factor for agriculture development (Shefaat, 2006). Wheat is the main crop in the region with a mean yield of $650 \mathrm{~kg} \mathrm{ha}^{-1}$ (Iranian Agriculture Ministry, 2009). It is widely adopted as a monoculture crop, with the growing period between March and July, and October and July for spring and winter-sown, respectively.

Improving water use efficiency has been an urgent issue in the region as ecological water demand has been increasingly concerned. Determining factors affecting the RWUE and quantification their effects value are important to model the RWUE and predict crop yield in the area. Some authors have investigated various factors influencing the RWUE, which include cropping systems (Kar et al., 2006; Rao, 2008), fertilization (Rao et al., 2010), mulch (Rehman et al., 2009) and tillage (Ronner, 2011), previously. Up to now, the effect of soil properties on the RWUE has not been quantitatively investigated; therefore, the objective of this work was to quantify the influence of soil properties on the RWUE and model it in dry-farming lands of the semi-arid region.

\section{Materials and Methods}

\subsection{Study Area}

The study was carried out in a semi-arid area of northwest of Iran located in Hashtroud township (southern part of East Azarbyjan province) from March 2005 to March 2006. The study zone was $900 \mathrm{~km}^{2}$ in area located between $37^{\circ} 18^{\prime} 49^{\prime \prime}$ and $37^{\circ} 35^{\prime} 0^{\prime \prime} \mathrm{N}$ latitude, and $46^{\circ} 46^{\prime} 5^{\prime \prime}$ and $47^{\circ} 6^{\prime} 5^{\prime \prime} \mathrm{E}$ longitude (Figure 1). The climate is semi-arid with an average annual precipitation of $322 \mathrm{~mm}$, mostly falling as snow in the winter and autumn and as rain in the spring, and a mean annual temperature of $13^{\circ} \mathrm{C}$. Agricultural soils located mostly in $5-15 \%$ slopes (Hakimi, 1986) and mainly are utilized for wheat production under rainfed condition. Soils according to USDA Soil Taxonomy classification system (Soil Survey Staff, 1975) were classified as calcixerepts (Banaee, 1999). Soils were mostly tilled and planted in slope direction. So, as noted by Blanco and Lal (2008) surface runoff rapidly concentrates in furrows and immediately flows up- and down-slope direction.

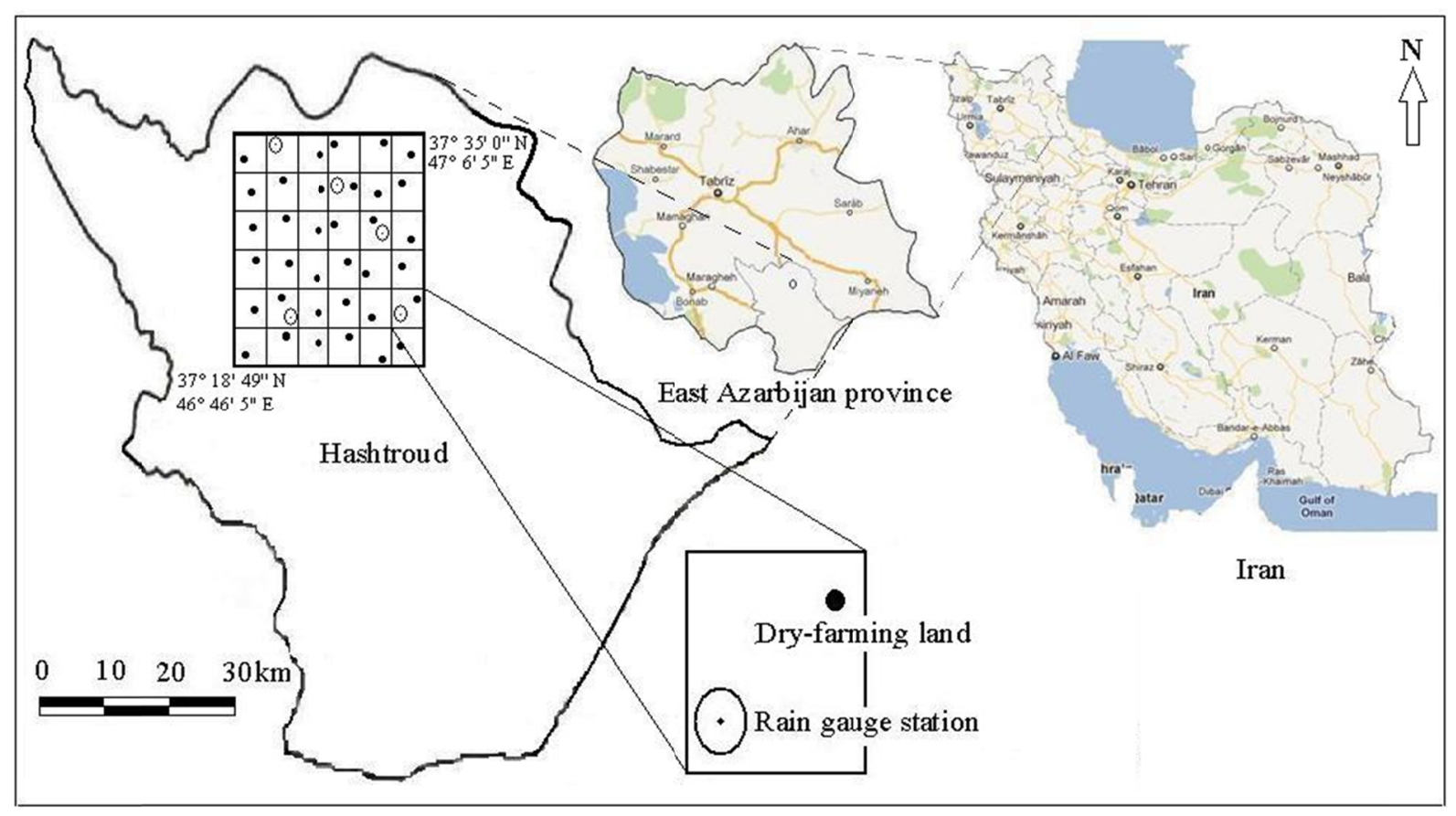

Figure 1. Location of the study area, dry-farming lands and rain gauge stations 


\subsection{Determination of the RWUE}

Based on the water use efficiency definition that refers to the ratio of economic yield to water consumed by the crop (Katerji et al., 2008), rainwater use efficiency (RWUE) obtained from the ratio of crop dry matter (CDM) per unit of the abstracted rainwater volume (ARWV) as fallowing:

$$
R W U E=\frac{C D M}{A R W V}
$$

where RWUE was in $\mathrm{kg} \mathrm{m}^{-3}$, CDM was in $\mathrm{kg}$ and ARWV was in $\mathrm{m}^{3}$. The abstracted rainfall volume (ARWV) obtained from differentiation of the rainfall volume $\left(\mathrm{m}^{3}\right)$ and runoff volume $\left(\mathrm{m}^{3}\right)$ during a two-growth period.

\subsubsection{Installation of the Crop and Runoff Plots}

Thirty six dry-farming lands were considered in the study area to installation of crop plots and runoff plots (Figure 1). The crop plots and runoff plots were separately installed in a $200 \mathrm{~m}^{2}$ area at three replications beside together in each dry land at the same time. In fact crop yield and runoff volume were separately determined at 108 plots during a two-growth period for a two-study period (2005-2007). The crop and runoff plots were established based on USLE standard/unit plots (Wischmeier \& Smith, 1978) with $22.1 \mathrm{~m}$ length in slope direction and $1.83 \mathrm{~m}$ width and a buffer bed about $1.2 \mathrm{~m}$ between two plots. The plots were plowed and accordingly disked up to down slope at middle October 2005. For providing similar conditions between the crop plots and runoff plots, was avoided from fertilizer application to enhance crop yield in the planted area.

\subsubsection{Determination of Wheat Yield}

The Sardary winter wheat variety, normally grown for bread, was planted at the crop plots by a drill in depth of 4-6 $\mathrm{cm}$, with $20 \mathrm{~cm}$ row spacing and $5 \mathrm{~cm}$ plant spacing right after plowing at last October 2005. Length of growing period of the winter wheat was about eight months and on July 25, the crop was harvested for determining grain yield. Plant samples were randomly taken from three $1 \mathrm{~m}^{2}$ locations from each plot area by clipping the plants at the soil surface and accordingly mean grain yield of each plot was computed. Mean grain yield and mean dry matter of each dry-farming land $\left(\mathrm{kg} \mathrm{ha}^{-1}\right)$ were calculated from averaging the yield and biomass values of its three plots, respectively. The mean wheat yield and dry matter for a two-year study period were computed based on the yield and biomass values of the first and second year $\left(\mathrm{kg} \mathrm{ha}^{-1}\right)$.

\subsubsection{Determination of Surface Runoff Volume}

Surface runoff caused by natural rainfalls was measured at the lower parts of the runoff plots during a two-growth period for a two-study period (2005-2007). The plots were surrounded using $30 \mathrm{~cm}$ ridges and runoff-collecting installations consisted of gutter pipes, pipes and 70-1 tanks were established at their lower parts. After each natural rainfall event producing runoff at the plots, total contents (runoff-sediment) mass in the collecting tank was measured. Then, the tanks contents were mixed thoroughly and a $0.5 \mathrm{~kg}$ homogeneous sample was taken to determination of runoff mass. In the laboratory, the samples were weighed and evaporated on a hot plate then weighed again to determine runoff mass. Water loss of each plot was determined based on multiplying total contents mass of the tank by mass percentage of water in its sample. Annual surface runoff was also computed from summation of total surface runoffs produced in different rainstorms for a two-growth period.

\subsubsection{Determination of Rainfall Volume}

Rainfall volume $\left(\mathrm{m}^{3}\right)$ was calculated from multiplying the rainfall depth $(\mathrm{m})$ and plot area $\left(40.44 \mathrm{~m}^{2}\right)$. Rainfall data were taken from five rain gauge stations located in the study area (Figure 1). Four standard rainfall gauges located in the grids 2, 10, 27 and 30 were used to manually measure the depth of rain after occurring the runoff at the plots. An automatic rain gauge station located in the grid 17 was also used to determine intensity of rainfall events. Rainfall data for a two- growth period was also used to determine spatial variations of the rainfall amounts in the study area.

\subsection{Determination of Soil Properties}

To determine soil properties in each dry-farming land, soil samples $(0-30 \mathrm{~cm}$ depth) were taken randomly from three locations within each plot before plowing. Then, the samples were mixed together to provide a representative sample from each plot. After being dried, the soil samples were grounded to pass a $2 \mathrm{~mm}$ sieve and stored in sealed polyethylene bags in a cool and dry place until the chemical analysis in the laboratory. The particle size distribution consisted of sand $(0.05-2 \mathrm{~mm})$, silt $(0.002-0.05)$ and clay $(<0.002 \mathrm{~mm})$ was determined by the Robinson's pipette method (SSEW, 1982). Gravel (2-8 mm) was determined using the weighting method (Gee \& Bauder, 1980). The total soil organic carbon was measured by the Walkley-Black wet dichromate oxidation method (Nelson \& Somers, 1982) and converted to organic matter through multiplying it by 1.724 . To 
determine soils carbonates (lime), the total neutralizing value (TNV) on the basis of calcium carbonate was measured using acid acetic volume consumed to neutralization of carbonates (Goh, Arnaud, \& Mermut, 1993). The aggregate stability was determined using the wet-sieving method based on the mean weight diameter (MWD) as proposed by Angers and Mehuys (1993). The water-stable aggregates were determined by placing $100 \mathrm{~g}$ soil surface aggregates with diameter larger than six mm on the top of sieves set and moved up to down in a water cylinder for one minute. Soil infiltration capacity was determined by measuring the one-dimensional water flow into the soil per unit time by double-ring infiltrometer (Bouwer, 1986) at four to six replications at the plots during dry period (in July 2005). Available water (AW) for each soil obtained from difference of mass soil moisture contents between the holding capacity (FC) and permanent wilting point (PWP). Soil moisture content by mass at FC (-30 kPa matric potential) and PWP (-1500 kPa matric potential) were measured using a pressure plate and pressure membrane apparatus, respectively (Hillel, 1982).

\subsection{Statistical Analysis}

Soil, rainfall and runoff data were assessed for normality using the Kolmogorov-Smirnov test before analysis. Differences in rainfall amounts among rain gauge stations were analyzed using one-way ANOVA. Relationship between runoff and rainfall was extracted using the different equations based on the highest determination coefficient $\left(\mathrm{R}^{2}\right)$. Runoff and RWUE difference among the plots was analyzed using Duncan's parametric test. Soil properties influencing the RWUE were extracted based on bivariate Pearson's correlation matrix. A stepwise multiple regression analysis was applied to develop a relationship between the RWUE and the effective soil properties. SPSS 18 software was used, and the significance level was $95 \%(p<0.05)$ in all statistical analyses.

\section{Results and Discussion}

\subsection{Rainfall Characteristics}

Annual rainfall amount in the first and second study year was $249.3 \mathrm{~mm}$ and $159.5 \mathrm{~mm}$, respectively. Thirty six and twenty seven natural rainfall events occurred in the study area during the growth period in the first and second study year, respectively. Table 1 shows the statistical characteristics of the rainfall events in the first and second study year. Rainfall intensity in the first year varied from 0.1 to $13.78 \mathrm{~mm} \mathrm{~h}^{-1}$ with an average of 3.25 $\mathrm{mm} \mathrm{h}^{-1}$. Rainfall intensity in the second year was between 0.31 to $8.20 \mathrm{~mm} \mathrm{~h}^{-1}$ with an average of $2.57 \mathrm{~mm} \mathrm{~h}^{-1}$. Total rainfall height during the growth period in the first and second year was $151.41 \mathrm{~mm}$ and $93.95 \mathrm{~mm}$, respectively. There was no significant difference among the rainfall depth values in different rain gauge stations $(\mathrm{F}=0.03$, $\mathrm{p}$-value $=0.99)$. In fact, spatial variations of the rainfall events were uniform in the study area.

Table 1. The statistical characteristics of the rainfall events in the growth period in the first and second study year

\begin{tabular}{ccccccc}
\hline \multirow{2}{*}{ Growth Periods } & \multicolumn{2}{c}{ Height $(\mathrm{mm})$} & & \multicolumn{2}{c}{ Intensity $\left(\mathrm{mm} \mathrm{h}^{-1}\right)$} \\
\cline { 2 - 3 } \cline { 5 - 6 } & Mean & StD. & & Mean & StD. \\
\hline 2005 & 4.21 & 4.52 & & 3.25 & 2.81 \\
2006 & 3.48 & 2.84 & & 2.57 & 1.99 \\
\hline
\end{tabular}

\subsection{Runoff and RWUE}

Nineteen rainfall events and thirteen rainfall events produced runoff at the plots in the first and second growth period, respectively. Table 2 shows rainfall height and runoff depth in the rainstorms in the first and second growth period in the study area.

Mean surface runoff during the growth period in the first study year varied from 2.15 lit to 49.37 lit with an average of 17.13 lit. It was between 1.79 lit and 27.67 lit with an average of 10.63 lit in the second growth period. The abstracted rainfall water volume (ARWV) values were ranged from 74.36 lit to 696.83 lit and from 127.38 lit to 485.95 lit in the first and the second growth period, respectively.

Runoff depth significantly affected by rainfall height $\left(\mathrm{R}^{2}=0.70, \mathrm{p}<0.001\right)$. With an increasing rainfall height, runoff remarkably increased (Figure 2). Rainfall having a height of $17.1 \mathrm{~mm}$ had the highest potential to generate runoff in the study area. The highest productive runoff had a height of $17.1 \mathrm{~mm}$ that could produce $0.8 \mathrm{~mm}$ runoff in the study plots. Rainfalls that had a height value lower than $1.7 \mathrm{~mm}$ did not had any potential in runoff production in the study area. The abstracted rainfall significantly correlated with the rainfall $\left(\mathrm{R}^{2}=0.99, \mathrm{p}<\right.$ $0.001)$. 
Table 2. Rainfall height and runoff depth in the rainstorms in the first and second growth period

\begin{tabular}{|c|c|c|c|c|c|}
\hline \multicolumn{6}{|c|}{ Growth Periods } \\
\hline \multicolumn{3}{|c|}{2005} & \multicolumn{3}{|c|}{2006} \\
\hline Date & $\begin{array}{c}\text { Rainfall } \\
(\mathrm{mm})\end{array}$ & $\begin{array}{l}\text { Runoff } \\
(\mathrm{mm})\end{array}$ & Date & $\begin{array}{c}\text { Rainfall } \\
(\mathrm{mm})\end{array}$ & $\begin{array}{c}\text { Runoff } \\
(\mathrm{mm})\end{array}$ \\
\hline April 2 & 2.5 & 0.053 & March 29 & 5.3 & 0.130 \\
\hline April 3 & 3.65 & 0.106 & April 5 & 4.2 & 0.082 \\
\hline April 15 & 13.7 & 0.803 & April 7 & 6.7 & 0.093 \\
\hline April 16 & 2.7 & 0.103 & April 17 & 12.7 & 0.684 \\
\hline April 17 & 4.8 & 0.231 & April 24 & 4.2 & 0.168 \\
\hline April 18 & 3.7 & 0.181 & April 25 & 3.3 & 0.150 \\
\hline April 26 & 17.8 & 0.620 & April 26 & 5.6 & 0.369 \\
\hline April 27 & 2.8 & 0.314 & may 3 & 8.1 & 0.499 \\
\hline May 3 & 8.3 & 0.412 & May 4 & 4 & 0.350 \\
\hline May 4 & 2 & 0.085 & May 5 & 3.4 & 0.193 \\
\hline May 5 & 2.5 & 0.234 & May 6 & 4.8 & 0.268 \\
\hline May 6 & 4.2 & 0.302 & May 10 & 6.8 & 0.385 \\
\hline May 14 & 11.9 & 0.982 & June 25 & 4.1 & 0.044 \\
\hline May 15 & 12.4 & 1.221 & & & \\
\hline May 16 & 8.1 & 0.698 & & & \\
\hline May 19 & 12.5 & 0.557 & & & \\
\hline May 20 & 10.4 & 0.717 & & & \\
\hline May 31 & 3.5 & 0.365 & & & \\
\hline June 2 & 1.9 & 0.061 & & & \\
\hline
\end{tabular}
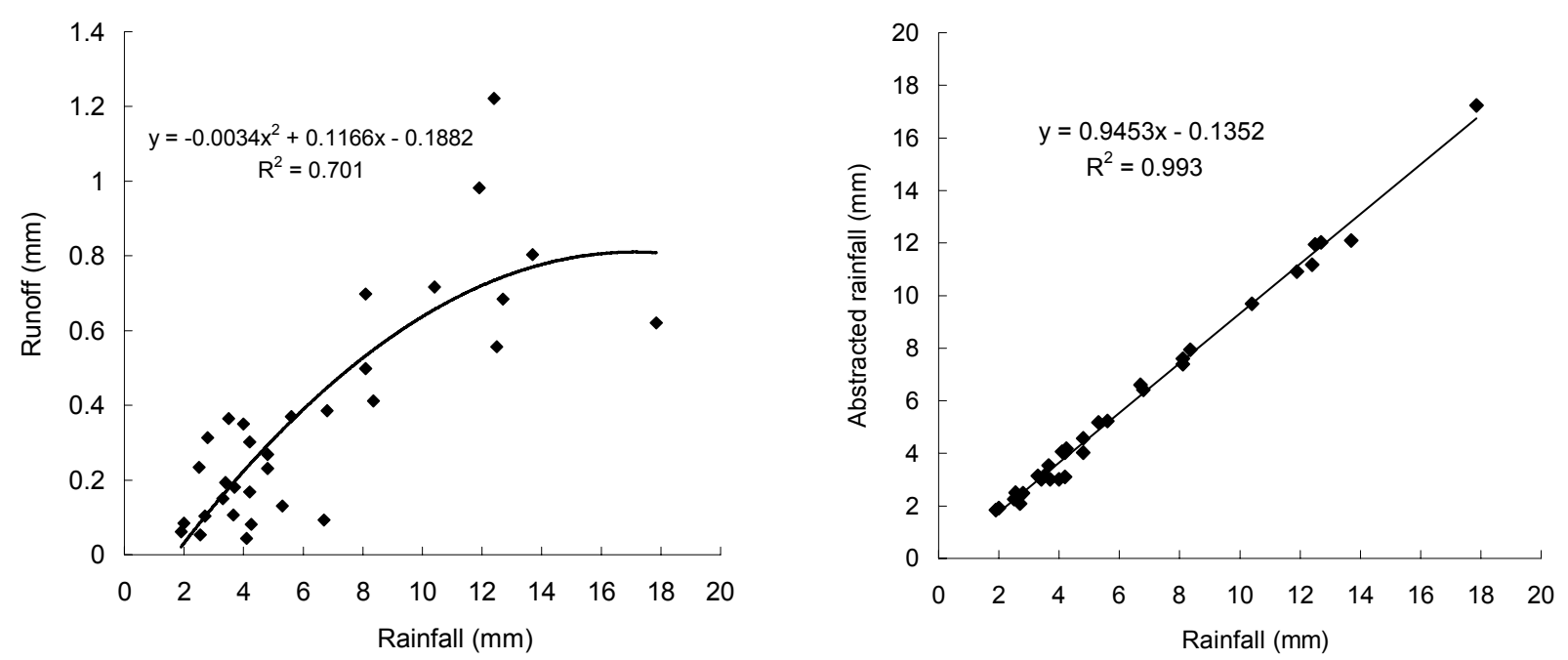

Figure 2. Relationship between runoff and abstracted rainfall, and rainfall during a two-growth period

Both runoff and the abstracted rainfall water volume (ARWV) significantly $(\mathrm{p}<0.001)$ varied among the plots installed in 36 dry farming lands (Table 3). Since the spatial distribution of the rainfalls were uniform in the study area, differences of the runoff and ARWV among the dry-farming lands directly related to soil properties. 
Table 3. Analysis of variance of mean runoff and ARWV in the dry-farming lands

\begin{tabular}{lrrccc}
\hline Variable & Sum of squares & DF & Mean square & F & Significant level \\
\hline Runoff & 421190.955 & 35 & 12034.027 & 45.531 & 0.000 \\
ARWV & 609780.425 & 35 & 17422.298 & 62.609 & 0.000 \\
\hline
\end{tabular}

\subsection{Wheat Yield and RWUE}

Mean annual wheat grain yield values in the dry-farming lands were ranged from $801.4 \mathrm{~kg} \mathrm{ha}^{-1}$ to $3484.3 \mathrm{~kg} \mathrm{ha}^{-1}$ with an average of $1937.8 \mathrm{~kg} \mathrm{ha}^{-1}$. Mean annual rainfall water use efficiency (RWUE) values were between 0.72 and $3.13 \mathrm{~kg} \mathrm{~m}^{-3}$. Table 4 shows mean annual wheat grain yield and RWUE in 36 dry farming lands. Both wheat yield and RWUE considerably $(\mathrm{p}<0.001$ ) varied among the dry farming lands (Table 5). Difference of the yield among dry-lands was only due to variations of the soil properties in dry-farming lands.

Table 4. Mean wheat grain yield and RWUE in 36 dry farming lands in the study area

\begin{tabular}{|c|c|c|c|c|c|c|c|c|}
\hline $\begin{array}{l}\text { Land } \\
\text { No. }\end{array}$ & $\begin{array}{l}\text { Wheat yield } \\
\qquad\left(\mathrm{kg} \mathrm{ha}^{-1}\right)\end{array}$ & $\begin{array}{l}\text { RWUE } \\
\left(\mathrm{kg} \mathrm{m}^{-3}\right)\end{array}$ & $\begin{array}{l}\text { Land } \\
\text { No. }\end{array}$ & $\begin{array}{l}\text { Wheat yield } \\
\qquad\left(\mathrm{kg} \mathrm{ha}^{-1}\right)\end{array}$ & $\begin{array}{l}\text { RWUE } \\
\left(\mathrm{kg} \mathrm{m}^{-3}\right)\end{array}$ & $\begin{array}{c}\text { Land } \\
\text { No. }\end{array}$ & $\begin{array}{l}\text { Wheat yield } \\
\qquad\left(\mathrm{kg} \mathrm{ha}^{-1}\right)\end{array}$ & $\begin{array}{l}\text { RWUE } \\
\left(\mathrm{kg} \mathrm{m}^{-3}\right)\end{array}$ \\
\hline 1 & 801.4 & 0.72 & 13 & 1559.0 & 1.41 & 25 & 1376.3 & 1.24 \\
\hline 2 & 1125.4 & 1.01 & 14 & 2118.6 & 1.92 & 26 & 2970.3 & 2.66 \\
\hline 3 & 834.6 & 0.75 & 15 & 1445.4 & 1.31 & 27 & 3476.5 & 3.13 \\
\hline 4 & 2540.3 & 2.28 & 16 & 3263.7 & 2.81 & 28 & 1187.5 & 1.07 \\
\hline 5 & 1130.3 & 1.02 & 17 & 3396.0 & 2.91 & 29 & 1846.7 & 1.66 \\
\hline 6 & 2641.7 & 2.35 & 18 & 1724.3 & 1.48 & 30 & 1202.7 & 1.09 \\
\hline 7 & 1256.7 & 1.12 & 19 & 1234.5 & 1.07 & 31 & 2340.8 & 2.14 \\
\hline 8 & 3484.3 & 3.12 & 20 & 2443.3 & 2.14 & 32 & 3316.4 & 3.02 \\
\hline 9 & 1265.7 & 1.13 & 21 & 3470.9 & 3.03 & 33 & 1484.5 & 1.33 \\
\hline 10 & 1176.9 & 1.05 & 22 & 1757.8 & 1.53 & 34 & 2174.4 & 1.89 \\
\hline 11 & 1364.5 & 1.22 & 23 & 1017.8 & 0.88 & 35 & 1446.6 & 1.25 \\
\hline 12 & 3017.7 & 2.67 & 24 & 1543.7 & 1.33 & 36 & 1323.2 & 1.15 \\
\hline
\end{tabular}

Table 5. Analysis of variance of wheat grain yield and RWUE in the dry-farming lands

\begin{tabular}{lccccc}
\hline \multicolumn{1}{c}{ Variable } & Sum of squares & DF & Mean square & F & Significant level \\
\hline Wheat yield & $5.711 * 10^{7}$ & 35 & 1631653.076 & 71.413 & 0.000 \\
RWUE & $56.394 * 10^{7}$ & 35 & 1.611 & 67.591 & 0.000 \\
\hline
\end{tabular}

\subsection{Soil Properties}

Soil physicochemical analysis indicated that the soils were mainly clay loam having $36.7 \%$ sand, $31.6 \%$ silt and $32.0 \%$ clay (Table 6 ). Soils had inherently low amount of organic matter (1.1\%) due to low plant growth caused by water stress and frequency cultivation without considering fallow condition. Soils were calcareous/limy with a relatively high value of carbonates (about $13 \%$ equivalent calcium carbonate /lime). Soil aggregates were mainly granular and mean wheat diameter of the water-stable aggregates was very low $(1.13 \mathrm{~mm})$. The soils based on the SCS method (USDA, SCS, 1991) were mostly classified in C hydrological grope with a mean infiltration capacity of $3.5 \mathrm{~cm} \mathrm{~h}^{-1}$. 
Table 6. Soil properties in the study area

\begin{tabular}{lcc}
\hline Soil property & Mean & St.D. \\
\hline Sand & 36.72 & 6.69 \\
Silt & 31.59 & 7.12 \\
Clay & 31.69 & 5.75 \\
Gravel & 9.89 & 2.37 \\
Organic matter & 1.09 & 0.25 \\
Carbonates/lime / (\%) & 12.66 & 5.25 \\
Porosity & 0.46 & 0.06 \\
Aggregate stability in Water, $(\mathrm{mm})$ & 1.13 & 0.44 \\
Infiltration capacity $\left(\mathrm{cm} \mathrm{h}^{-1}\right)$ & 3.56 & 1.17 \\
Available water $(\%)$ & 8.31 & 2.70 \\
\hline
\end{tabular}

\subsection{Relationship between the RWUE and Soil Properties}

As shown in Table 7, the RWUE significantly correlated with silt $(\mathrm{r}=-0.62, \mathrm{p}<0.01)$, clay $(\mathrm{r}=0.52, \mathrm{p}<0.01)$, $\mathrm{pH}(\mathrm{r}=0.44, \mathrm{p}<0.01)$, organic matter $(\mathrm{r}=0.68, \mathrm{p}<0.01)$, Nitrogen $(\mathrm{r}=0.28, \mathrm{p}<0.05)$, aggregate stability $(\mathrm{r}=$ $0.61, \mathrm{p}<0.01)$, infiltration capacity $(\mathrm{r}=0.68, \mathrm{p}<0.01)$ and available water $(\mathrm{r}=0.41, \mathrm{p}<0.05)$. With an increasing in clay, $\mathrm{pH}$, organic matter, Nitrogen, aggregate stability, infiltration capacity and available water, the RWUE remarkably improved. Aggregate stability, infiltration capacity and available water were the dependent soil variables that were affected by some independent soil properties. Aggregate stability positively correlated with clay, organic matter and lime, whereas sand as resulted by Moreno-de and Heras (2009) negatively affected it. Clay and organic matter as cementation collides encouraged soil particles to stick together and form the stable aggregates in the soils. Presence $\mathrm{Ca}^{2+}$ ion in the limey soil matrix also stimulated flocculation of soil colloids (Charman \& Murphy, 2000) and increased the aggregate stability. In some dry-lands, presence of the stable aggregates in the soil surface decreased runoff generation, and probably roots aeration due to enhancing resistance of the aggregates against the impact of raindrops and finally soil crusting. Other authors also found significant negative relationships between the aggregate stability and susceptibility to runoff (Reichert \& Norton, 1994; Amezketa, Singer, \& Le Bissonnais, 1996). Cantón et al. (2009) showed that the stability of topsoil aggregates can be a valuable indicator of field assessed runoff of sandy loam range soils under semiarid conditions. Infiltration capacity had the highest correlation with the RWUE because of its direct influence on the runoff generation. This result was in accord with Gómez et al. (2001), who found that approximately $50 \%$ of variability of runoff in fallow plots, can be explained by the final infiltration rate. Infiltration capacity increased with an increase in sand, organic matter and lime. Despite presence sand particles in soil decreased soil porosity, it caused more large pores (macropores) which allowed rapid entry of water into the soil. Organic matter increased water infiltration rate in the soil due to promoting aggregates formation and increasing macrospores proportion in the soil. Studies by Brakensiek and Rawls (1994) and Maestre and Cortina (2002) also indicated that spatial variability of the soil infiltration capacity is related to the high spatial variability of soil properties (organic matter content, structure) that affect the runoff generation in the hillslopes. The presence of organic matter in the soil also improved the soil-water availability due to increasing the water holding capacity (FC) of the soil as a result of the aggregates formation. In many studies, the effect of organic matter in improving the physical properties of soil, such as soil porosity, structure and water-holding capacity were well known (Oades, 1984; Lal, 1986; Lavelle, 1988). While findings of Katerji and Mastrorilli (2006) showed that the WUE was reduced significantly when crops (potato, corn, sunflower, and sugar beet) were grown in clay soil, in the present study clay positively affect on the RWUE. This result was due to strong role of clay in enhancing the stability of soil structure. While findings by Xiaoyan et al. (2002) showed that surface gravel mulch could negatively affect the runoff generation, gravel presence in soil matrix had no significant effect on the soil physical properties and in consequent the RWUE. Nevertheless, in some studies ( $\mathrm{Li}$ et al., 2000) benefits of Nitrogen (N) was a dependent element to organic matter which improves the crop yield and the RWUE. Deng et al. (2006) also reported that the use of nitrogen fertilizers was one of reasons of increasing the water use efficiency (WUE) in China from 1949 to 1996. Lime has been recognized as an important factor controlling runoff in the soils because $\mathrm{Ca}^{2+}$ cations could bind soil particles and improves the aggregates stability (Pepper \& Morrissey, 1985). 
Table 7. The correlation matrix of the RWUE and physicochemical soil properties in the study area

\begin{tabular}{|c|c|c|c|c|c|c|c|c|c|c|c|c|c|c|c|}
\hline & Gr & $\mathrm{Sa}$ & $\mathrm{Si}$ & $\mathrm{Cl}$ & F & $\mathrm{pH}$ & $\mathrm{EC}$ & $\mathrm{OM}$ & $\mathrm{Li}$ & $\mathrm{N}$ & K & AS & If & AW & RWUE \\
\hline Gr & 1 & & & & & & & & & & & & & & \\
\hline $\mathrm{Sa}$ & 0.02 & 1 & & & & & & & & & & & & & \\
\hline $\mathrm{Si}$ & 0.02 & $-0.68^{* *}$ & 1 & & & & & & & & & & & & \\
\hline $\mathrm{Cl}$ & -0.06 & $-0.38^{*}$ & $-0.41^{*}$ & 1 & & & & & & & & & & & \\
\hline $\mathrm{F}$ & -0.04 & $-0.39^{*}$ & -0.09 & $0.61^{* *}$ & 1 & & & & & & & & & & \\
\hline $\mathrm{pH}$ & -0.02 & -0.16 & $0-.21$ & $0.44^{* *}$ & 0.09 & 1 & & & & & & & & & \\
\hline $\mathrm{EC}$ & -0.07 & $-0.35^{*}$ & $0.41^{*}$ & -0.11 & -0.09 & -0.03 & 1 & & & & & & & & \\
\hline $\mathrm{OM}$ & 0.16 & 0.06 & -0.23 & 0.21 & $0.29^{\prime \prime}$ & 0.06 & 0.02 & 1 & & & & & & & \\
\hline $\mathrm{Li}$ & -0.03 & -0.27 & 0.17 & 0.03 & 0.02 & $0.47^{* * *}$ & $0.36^{*}$ & 0.05 & 1 & & & & & & \\
\hline $\mathrm{N}$ & 0.13 & -0.03 & -0.09 & 0.24 & $0.55^{* * *}$ & -0.08 & -0.06 & $0.60^{* * *}$ & -0.24 & 1 & & & & & \\
\hline $\mathrm{K}$ & 0.09 & -0.08 & -0.18 & $0.31^{*}$ & 0.16 & 0.19 & -0.15 & 0.06 & -0.09 & -0.07 & 1 & & & & \\
\hline AS & -0.09 & $-0.46^{* *}$ & -0.12 & $0.70^{* *}$ & $0.48^{* * *}$ & $0.56^{* * *}$ & 0.24 & $0.29^{*}$ & $0.48^{* * *}$ & 0.22 & 0.22 & 1 & & & \\
\hline If & 0.09 & $0.57^{* * *}$ & $-0.55^{* *}$ & -0.07 & -0.16 & 0.26 & -0.14 & $0.54^{* * *}$ & $0.29^{*}$ & 0.11 & 0.08 & 0.13 & 1 & & \\
\hline $\mathrm{AW}$ & 0.22 & 0.26 & -0.18 & -0.07 & 0.27 & -0.01 & -0.04 & $0.55^{* *}$ & -0.10 & $0.55^{* *}$ & -0.08 & 0.10 & $0.33^{*}$ & 1 & \\
\hline RWUE & 0.04 & 0.19 & $-0.62^{* * *}$ & $0.52^{* *}$ & 0.23 & $0.44^{* * *}$ & -0.03 & $0.68^{* * *}$ & $0.30^{*}$ & $0.28^{*}$ & 0.16 & $0.61^{* * *}$ & $0.68^{* * *}$ & $0.41^{*}$ & 1 \\
\hline
\end{tabular}

Gr: gravel; Sa: sand; Si: silt; Cl: clay; F: porosity; pH: potential of hydronium ions; EC: electrical conductivity; OM: organic matter; Li: lime (carbonates); N: nitrogen; K: potassium; AS: aggregate stability; If: infiltration capacity; AW: available water; RWUE: rainfall water use efficiency.

The stepwise multiple regression analysis of the relationship between the RWUE and soil properties showed that the RWUE significantly $\left(\mathrm{R}^{2}=0.85, \mathrm{p}<0.001\right)$ related to silt, organic matter and lime (Table 8$)$. Organic matter and lime contrary to silt improved the RWUE in the dry-farming lands. These properties considerably enhanced either the soil infiltration capacity or the soil available water. As well known by Hartanto et al. (2003) and Zhang et al. (2007b), organic matter was the most important binding and bridging agent in enhancing the soil's structural stability, infiltration capacity, and in consequence reducing runoff in the study area. Besides this, organic matter was only effective factor influencing the soil available water and plant growth (Zhang et al., 2007a). Since the soil organic matter is strongly affected by tillage methods such as crop residues and cultivation systems, it can be considered the only management soil factor influencing the RWUE in the study area. Thus, adding organic matter to the soil through maintaining crop residues is a proper technique and sustainable strategy to improve the soil properties (Shaver, 2010), prevention of the excessive soil water evaporation (Howell et al., 1990), decline runoff (Freebairn \& Boughton, 1985) and enhance the RWUE in the dry-farming lands. Contour farming is another effective method to prevent runoff generation (Blanco \& Lal, 2008; Gebreegziabher et al., 2009) and soil nutrients loss and promote soil physicochemical properties in order to the effective use from rain waters in the sloped dry-farming lands.

Table 8. The multi-regression analysis of the relationship between RWUE and some dependent soil properties

\begin{tabular}{|c|c|c|c|c|c|}
\hline \multirow{2}{*}{ Model variable } & \multicolumn{2}{|c|}{ Unstandardized coefficients } & \multirow{2}{*}{$\begin{array}{l}\text { Standardized } \\
\text { coefficient }\end{array}$} & \multirow{2}{*}{ t-level } & \multirow{2}{*}{ p-level } \\
\hline & Model coefficients & Standard error & & & \\
\hline Constant & -2.563 & 0.316 & & -8.101 & $\mathrm{p}<0.001$ \\
\hline 1/Silt & -56.458 & 6.754 & 0.588 & 8.360 & $\mathrm{p}<0.001$ \\
\hline Organic matter & 1.582 & 0.210 & 0.523 & 7.523 & $\mathrm{p}<0.001$ \\
\hline Lime & 0.054 & 0.010 & 0.367 & 5.370 & $\mathrm{p}<0.001$ \\
\hline
\end{tabular}


A regression equation was developed based on the relationship between the RWUE and the effective soil properties:

$$
\text { RWUE }=-56.458 / \text { Silt }+1.582 \text { OM }+0.054 \text { Lime }
$$

where the RWUE was in $\mathrm{kg} \mathrm{m}^{-3}$, silt, $\mathrm{OM}$ and lime were in percent.

\section{Conclusions}

The study indicated that the RWUE (Rainfall water use efficiency) in rainfed conditions remarkably affected by soil properties in the dry-farming lands. Soil properties which considerably enhanced either the water infiltration rate into the soil or the water availability to plant could also improve the RWUE in the study area. The RWUE significantly $\left(R^{2}=0.85, p<0.001\right)$ related to silt, organic matter and lime. Organic matter and lime positively affected on the soil structure, water infiltration rate and water-holding capacity, while silt inversely affected these soil physical parameters and in consequence the RWUE in the study area. A regression equation was developed based on theses soil properties to predict the RWUE in the study area. Organic matter was only the most important management factor influencing the physic-chemical properties and controlling the RWUE in the study area. Therefore, adding organic matter to the soil through maintaining crop residues is a proper technique and sustainable strategy to improve the soil physic-chemical properties and enhance the RWUE in the dry-farming lands. Contour farming is another effective approach to prevent runoff generation, conserve soil and nutrients, and promote soil physicochemical properties to the effective use of rains in the sloping fields.

\section{Acknowledgements}

We thank the regions farmers for providing dry-farming lands to establish field experiments and the Irrigation Office of Hashtroud for providing the rain gauges data.

\section{References}

Amezketa, E., Singer, M. J., \& Le Bissonnais, Y. (1996). Testing a new procedure for measuring water-stable

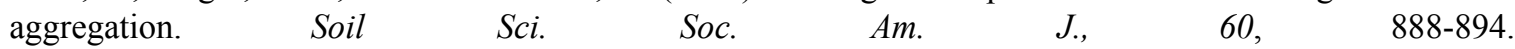
http://dx.doi.org/10.2136/sssaj1996.03615995006000030030x

Angers, D. A., \& Mehuys, G. R. (1993). Aggregate stability to water. In M. R. Cartner (Ed.), Soil sampling and methods of analysis (pp. 651-657). Canadian Society of Soil Science. Lewis Publishers, Boca Raton, Canada.

Anonymous. (2011). Tabriz Climate Guide. Shootingonlocation.com.

Asseng S., Dunin, F. X., Fillery, I. R. P., Tennant, D., \& Keating, B. A. (2001). Potential deep drainage under wheat crops in a Mediterranean climate. II. Management opportunities to control drainage. Aust. J. Agr. Res., 52, 57-66. http://dx.doi.org/10.1071/AR99187

Banaee, M. R. (1999). Map of thermal and moisture soils regimes of Iran. Soil and Water Research Institute, Iranian Agriculture Ministry, Research Report, 823, 14-23. (In Persian)

Blanco, H., \& Lal, R. (2008). Principles of Soil Conservation and Management (pp. 180-181). Retrieved from springer.com

Blum, A. (2009). Effective use of water (EUW) and not water-use efficiency (WUE) is the target of crop yield improvement under drought stress. Field Crops Res., 112, 119-123. http://dx.doi.org/10.1016/j.fcr.2009.03.009

Bouwer, H. (1986). Intake rate: Cylinder infiltrometer. In A. Klutem (Ed.), Methods of Soil Analysis, Part 1, Physical and Mineralogical Methods, Second addition (pp. 341-345). Madison, Wisconsin, USA: Agronomy Soil Science Society of America, Inc.

Brakensiek, D. L., \& Rawls, W. J. (1994). Soil containing rock fragments: effects on infiltration. Catena, 23, 99-110. http://dx.doi.org/10.1016/0341-8162(94)90056-6

Cantón, Y., Solé-Benet, A., Asensio, C., Chamizo, S., \& Puigdefábregas, J. (2009). Aggregate stability in range sandy loam soils, relationships with runoff and erosion. Catena, 77, 192-199. http://dx.doi.org/10.1016/j.catena.2008.12.011

Charman, P. E. V., \& Murphy, B. W. (2000). Soils (their properties and management) (2nd Edn, pp. 206-212). Land and Water Conservation. New South Wales, Oxford.

Deng, X. P., Shan, L., Zhang, H., \& Turner, N. C. (2006). Improving agricultural water use efficiency in arid and semiarid areas of China. Agric. Water Manage., 80, 23-40. http://dx.doi.org/10.1016/j.agwat.2005.07.021 
Freebairn, D. M., \& Boughton, W. C. (1985). Hydrologic effects of crop residue management practices. Aust. J. Agr. Res., 23(1), 23 -35.

Gebreegziabher, T., Nyssen, J., Govaerts, B., Getnet, F., Behailu, M., ... Deckers, J. (2009). Contour furrows for in situ soil and water conservation, Tigary, Northern Ethiopia. Soil Till. Res., 103(2), 257-264. http://dx.doi.org/10.1016/j.still.2008.05.021

Gee, G. W., \& Bauder, J. W. (1980). Particle-size analysis. In A. Klutem (Ed.), Methods of Soil analysis, Part 1, Physical and Mineralogical Methods, (2nd ed.). Madison, Wisconsin, USA: AGRONOMY, Soil Science Society of America, Inc.

Ghawi, I., \& Battikhi, A. (1986). Water melon production under mulch and trickle irrigation in the Jordan valley. $J$. Agron. Crop Sci., 157, 145-155. http://dx.doi.org/10.1111/j.1439-037X.1986.tb00062.x

Goh, T. B., Arnaud, R. J. St., \& Mermut, A. R., (1993). Aggregate stability to water. In M. R. Cartner (Ed.), Soil sampling and methods of analysis. Canadian Society of Soil Science. Lewis Publishers, Boca Raton, Canada.

Gómez, J. A., Nearing, M. A., Giráldez, J. V. \& Alberts, E. E. (2001). Analysis of sources of variability of runoff volume in a 40 plot experiment using a numerical model. J. Hydrol., 248(1-4), 183-197. http://dx.doi.org/10.1016/S0022-1694(01)00402-4

Hakimi, A. (1986). The briefly study of soil science in Hashtrood. Soil and Water Research Institute, Iranian Agriculture Ministry, Research Report, 767, 2-15 (In Persian).

Hartanto, H., Prabhu, R., Widayat, A. S. E., \& Asdak, C. (2003). Factors affecting runoff and soil erosion: plot-level soil loss monitoring for assessing sustainability of forest management. Forest Ecolo. Manag., 180(4), 361-374. http://dx.doi.org/10.1016/S0378-1127(02)00656-4

Hillel, D. (1982). Introduction to soil physics. Academic Press, New York.

Howell, T. A., Cuenca, R. H., \& Solomon, K. H. (1990). Crop yield response. In G. J., Hoffman, T. A., Howell \& K. H., Solomon (Eds.), Management of Farm Irrigation Systems (pp. 93-122). ASAE, St. Joseph, M.I.

Iranian Agriculture Ministry. (2009). Results of statistical studies on wheat and barley. Statistical and Information Technology Service (pp. 2-5). (In Persian)

Kar, G., Verma, H. N., \& Singh, R. (2006). Enhancing rainwater-use efficiency and stabilizing productivity of rainfed upland through rice (Oryza sativa)-based intercropping. Indian J. Agr. Sci., 76(1), 33-36. http://dx.doi.org/10.1016/j.eja.2007.12.003

Katerji, N., \& Mastrorilli, M. (2006). The effect of soil texture on the water use efficiency of irrigated crops: Results of a multi-year experiment carried out in the Mediterranean region. Eur. J. of Agron., 30, 95-100.

Katerji, N., Mastrorilli, M., \& Ranab, G. (2008). Water use efficiency of crops cultivated in the Mediterranean region: Review and analysis. Eur. J. of Agron., 28, 493-507. http://dx.doi.org/10.1016/j.eja.2008.07.009

Lal, R. (1986). Soil surface management in the tropics for intensive land use and high and sustained production. Adv. Soil S., 5, 1-109.

Lavelle, P. (1988). Earthworms activity in the soil system. Biol. Fertil. Soil, 6, 237-251. http://dx.doi.org/10.1007/BF00260820

Li, X. Y., Gong, J. D., Gao, Q. Z., \& Wei, X. H. (2000). Rainfall interception loss by pebble mulch in the semi-arid region of China. J. Hydrol., 228, 165-173. http://dx.doi.org/10.1016/S0022-1694(00)00152-9

Maestre, F. T., \& Cortina, J. (2002). Spatial patterns of surface soil properties and vegetation in a Mediterranean semi-arid steppe. Plant Soil, 241, 279-291. http://dx.doi.org/10.1023/A:1016172308462

Modarres, R. (2006). Regional precipitation climates of Iran. J. Hydrol. (NZ), 45(1), 13-27.

Morell, F. J., Lampurlane's, J., A'lvaro-Fuentes, J., \& Cantero-Martı'nez, C. (2011). Yield and water use efficiency of barley in a semiarid Mediterranean agroecosystem: Long-term effects of tillage and $\mathrm{N}$ fertilization. Soil Till. Res., 117, 76-84. http://dx.doi.org/10.1016/j.still.2011.09.002

Moreno-de, M., \& Heras, L. (2009). Development of soil physical structure and biological functionality in mining soils affected by soil erosion in a Mediterranean-Continental environment. Geoderma, 149(3-4), 249-256. http://dx.doi.org/10.1016/j.geoderma.2008.12.003

Nelson, D. W., \& Sommer, L. E. (1982). Total carbon, organic carbon, and organic matter. In A. L. Page (Ed.), Methods of Soil Analysis (2nd ed., pp. 539-576). ASA Monogr. 9(2). Amer. Soc. Agron. Madison, WI. USA. 
Oades, J. M. (1984). Soil organic matter and structural stability: mechanisms and implications for management. Plant Soil, 76, 319-337. http://dx.doi.org/10.1007/BF02205590

Pepper, R. G., \& Morrissey, J. G. (1985). Soil properties affecting runoff. J. Hydrol., 79(3-4), 301-310. http://dx.doi.org/10.1016/0022-1694(85)90060-5

Rao, A. S. (2008). Micro-meteorological variations and Rain water-use efficiency of a Silvi-pastoral system. $J$. Agrometeorol, 10, 137-140.

Rao, B. K. R., Sahrawat, K. L., Wani, S. P., \& Pardhasaradhi, G. (2010). Integrated nutrient management to enhance on-farm productivity of rainfed maize in India. Int. J. Soil Sci., 5(4), $216-225$. http://dx.doi.org/10.3923/ijss.2010.216.225

Rehman, S., Khalil, S. K., Rehman, A., Amanullah, A., Khan, A. Z., \& Shah, N. H. (2009). Micro-watershed enhances rain water use efficiency, phenology and productivity of wheat under rainfed condition. Soil Till. Res., 104, 82-87. http://dx.doi.org/10.1016/j.still.2008.12.013

Reichert, J. M., \& Norton, L. D. (1994). Aggregate stability and rain-impacted sheet erosion of air-dried and prewetted clayey surface soils under intense rain. Soil Sci., 158, 159-169. http://dx.doi.org/10.1097/00010694-199409000-00001

Richards, L. A., \& Wadleigh, C. H. (1952). Soil water and plant growth. In B. T. Shaw (Ed.), Soil Physical Conditions and Plant Growth (pp. 74-251). American Society of Agronomy Series Monographs, Volume II. New York: Academic Press.

Ronner, E. (2011). A study on the effects of mulch and no-tillage on the seasonal water balance in Laikipia District, Kenya. Master thesis Irrigation and Water Engineering submitted in partial fulfillment of the degree of Master of Science in International Land and Water Management at Wageningen University, the Netherlands.

Schwab, G. O., Fangmeier, D. D., Elliot, W. J., \& Frevert, R. K. (1993). Soil and water conservation engineering (4th ed.). USA: John Wiley \& Sons Inc.

Shaver, T. (2010). Crop Residue and Soil Physical Properties. Proceedings of the 22nd Annual Central Plains Irrigation Conference, Kearney, NE., February 24-25, 2010 (pp. 22-27). Available from CPIA, 760 N.Thompson, Colby, Kansas.

Shefaat, S. (2006). Agriculture in East-Azarbijan province. Retrieved from http://www.magiran.com/npview.asp?ID = 1323615 (In Persian)

Soil Survey Staff. (1975). Soil Taxonomy. A Basic System of Soil Classification for Making and Interpreting Soil Surveys. U.S. Department of Agriculture, Agriculture Handbook No. 436, Washington D.C.

SSEW (Soil Survey Laboratory Methods). (1982). Technical Monographs. No. 6. Harpenden, UK.

Turner, N. C. (2004). Agronomic options for improving rainfall-use efficiency of crops in dryland farming systems. J. Exp. Bot., Water-Saving Agriculture Special Issue, 55(407), 2413-2425.

USDA, SCS. (1991). Engineering field handbook: chapter 2-estimating runoff. In National engineering handbook. Washington, D.C.: U.S. Department of Agriculture, Soil Conservation Service: part 650.

Veihmeyer, F. J., \& Hendrickson, A. H. (1927). The relation of soil moisture to cultivation and plant growth. Proc. 1st Intern. Congr. Soil Sci., 3, 498-513.

Wischmeier, W. H., \& Smith, D. D. (1978). Predicting rainfall erosion losses: a guide to conservation planning. Agriculture Handbook, No. 537. US Department of Agriculture, Washington DC. USA.

Xiaoyan, L., Ruiling, Z., Jiadong, G., \& Zhongkui, X. (2002). Soil and water accumulation by gravel and sand mulches in Western Loess Plateau of Northwest China. 12th ISCO Conference. Beijing, China from 26-31 May.

Zhang, G. S., Chan, K. Y., Oates, A., Heenan, D. P., \& Huang, G. B. (2007b). Relationship between soil structure and runoff/soil loss after 24 years of conservation tillage, Soil Till. Res., 92, 122-128. http://dx.doi.org/10.1016/j.still.2006.01.006

Zhang, S. L., Simelton, E., Lovdahl, L., Grip, H., \& Chen D. L. (2007a). Simulated long-term effects of different soil management regimes on the water balance in the Loess Plateau, China. Field Crop Res, 100, 311-319. http://dx.doi.org/10.1016/j.fcr.2006.08.006 